\title{
PENERAPAN MODEL PEMBELAJARAN PROBLEM BASED INSTRUCTION UNTUK MENINGKATKAN HASIL BELAJAR MATAKULIAH KONSEP DASAR PKn SD PADA MAHASISWA PGSD
}

\author{
Eva Pasaribu', Hana Pasaribu' ${ }^{2}$ \\ ${ }^{1,2}$ Universitas HKBP Nommensen Pematangsiantar, Indonesia. \\ Email: pasaribueva32@gmail.com ${ }^{1}$, pasaribuhana98@gmail.com².
}

\begin{abstract}
This study aims to determine the increase in: (1) Learning activities of the Basic Concepts of Civics as seen from the affective and psychomotor domains of students in Sub-theme 1 The Diversity of My Nation Culture by using the Problem Based Instruction cooperative learning model. (2) Learning outcomes of students' Basic Concept of Civics in Deliberation material using the Problem Based Instruction learning model for PGSD students in group P2 HKBP Nommensen University Pematangsianta. This research is a basic research with the research subjects P2 PGSD group totaling 40 students. This research was conducted in two cycles. The data collection technique used is indirect communication techniques and the data analysis technique used is descriptive analysis.

The results showed that: (1) Student learning activities using the Problem Based Instruction model in Sub-theme 1 The diversity of my culture from the affective domain increased by an average of $38.36 \%$ (46.97\% in the first cycle to $85.33 \%$ in the cycle II). 2) Student learning activities using the Problem Based Instruction model in Sub-theme 1 Cultural diversity of my nation from the psychomotor realm increased by an average of $40.31 \%$ (41.72\% in cycle I to $82.03 \%$ in cycle II). 3) Student learning outcomes in Sub-theme 1 Cultural Diversity using the Problem Based Instruction model also increased, by $20 \%$ (67.50\% in cycle I to $87.50 \%$ in cycle II).
\end{abstract}

Keywords: Cooperative learning model, Problem Based Instruction

\begin{abstract}
ABSTRAK
Penelitian ini bertujuan untuk mengetahui peningkatan : (1) Aktivitas belajar Konsep Dasar PKn yang dilihat dari ranah afektif dan psikomotorik mahasiswa pada Subtema 1 Keberagaman Budaya Bangsaku dengan menggunakan model pembelajaran kooperatif Problem Based Instruction. (2) Hasil belajar Konsep Dasar PKn mahasiswa pada materi Musyawarah dengan menggunakan model pembelajaran Problem Based Instruction pada mahasiswa PGSD di group P2 Universitas HKBP Nommensen Pematangsiantar. Penelitian ini merupakan penelitian dasar dengan subjek penelitian group P2 PGSD yang berjumlah 40 siswa. Penelitian ini dilaksanakan dalam dua siklus. Teknik pengumpulan data yang digunakan adalah teknik komunikasi tidak langsung dan teknik analisis data yang digunakan adalah analisis deskriptif.

Hasil penelitian menunjukkan bahwa: (1) Aktivitas belajar mahasiswa dengan menggunakan model Problem Based Instruction pada Subtema 1 Keberagaman Budaya Bangsaku dari ranah afektif meningkat dengan rata-rata 38,36\% (46,97\% pada siklus I menjadi 85,33\% pada siklus II). 2) Aktivitas belajar mahasiswa dengan menggunakan model Problem Based Instruction pada Subtema 1 Keberagaman Budaya Bangsaku dari ranah psikomotorik meningkat dengan rata-rata 40,31\% (41,72\% pada siklus I menjadi 82,03\% pada siklus II). 3) Hasil belajar mahasiswa pada Subtema 1 Keberagaman Budaya Bangsaku dengan menggunakan model Problem Based Instruction juga meningkat, sebesar $20 \%(67,50 \%$ pada siklus I menjadi $87,50 \%$ pada siklus II).
\end{abstract}

Kata Kunci : Model pembelajaran kooperatif, Problem Based Instruction

\section{PENDAHULUAN}

Pendidikan Kewarganegaraan adalah salah satu mata pelajaran yang inovatif untuk membuka jalan ke arah mempersiapkan warga negara yang cerdas, kritis, kreatif dan rasional yang diberikan kepada mahasiswa dengan ilmu pengetahuan dan 
kemampuan dasar yang berkenaan dengan hubungan antara warga negara dengan negara, warga negara dengan sesama warga negara yang bertujuan agar menjadi warga negara yang dapat diandalkan oleh bangsa dan negara dalam kehidupan berbangsa dan bernegara.

Pendidikan Kewarganegaraan memegang peranan yang sangat besar dalam kehidupan sehari- hari, karena mata pelajaran ini bertujuan membentuk warga negara yang cerdas, terampil dan berkarakter baik serta setia kepada bangsa dan negara Indonesia yang berdasarkan pada Pancasila dan UUD 1945. Pendidikan Kewarganegaraan dapat menjadi pengikat untuk menyatukan visi mahasiswa yang beragam dari segi agama, sosio-kultural, bahasa, usia dan suku bangsa tentang budaya kebersamaan atau persatuan yang dapat mendukung tetap berdirinya NKRI.

Dengan belajar Pendidikan Kewarganegaraan, mahasiswa diharapkan menjadi warga negara yang memiliki rasa kebangsaan dan cinta tanah air, demokratis, berkeadaban, memiliki daya saing, disiplin, berpartisipasi aktif dalam membangun kehidupan yang damai berdasarkan sistem nilai Pancasila.

Akan tetapi banyak mahasiswa yang memiliki pandangan negatif terhadap pelajaran PKn. Banyak mahasiswa memandang mata pelajaran PKn sebagai pelajaran yang membosankan. Gejala yang lain terlihat pada kenyataannya, proses pendidikan tidak memberi jawaban bagi kebutuhan mahasiswa dan tidak membentuk mahasiswa menjadi seperti yang diharapkan. Hal ini diakibatkan karena dosen/ pendidik hanya menerapkan proses belajar yang hanya berorientasi pada penambahan ilmu pengetahuan saja. Dosen hanya menuang informasi yang mengakibatkan mahasiswa seringkali tidak memahami apa yang telah dipelajarinya dan tidak mampu mengaplikasikan ilmu yang telah diperolehnya. Berbagai masalah dalam kegiatan belajar mengajar tentu akan berpengaruh pada hasil belajar. Hal ini tampak dari ratarata hasil belajar mahasiswa yang tidak memenuhi syarat ketuntasan minimal. Seharusnya dalam proses pendidikan mahasiswa dibentuk menjadi pribadi yang dapat menghadapi tantangan dimasa depan.

Rendahnya hasil belajar mahasiswa terhadap pelajaran PKn dipengaruhi oleh factor interen dan factor eksteren. Adapun yang dimaksud dengan factor interen adalah factor yang bersumber dalam diri mahasiswa itu sendiri seperti factor kesehatan, minat, kemampuan belajar, dan lain sebagainya. Sedangkan yang dimaksud dengan factor eksteren adalah factor yang bersumber dari luar diri mahasiswa seperti keluarga, lingkungan sekolah dan lingkungan masyarakat. Minat belajar mahasiswa juga sangat mempengaruhi hasil belajar mahasiswa. Untuk belajar dengan baik, minat merupakan salah satu indicator yang harus diperhatikan, sebab tanpa adanya minat maka kegiatan belajar mahasiswa tidak akan pernah tercapai. Oleh karenanya dosen perlu menciptakan perkuliahan yang dapat menumbuhkan minat belajar mahasiswa . Model perkuliahan akan mengarahkan mahasiswa memahami mengapa mereka harus belajar, kemudian mengidentifikasi, mengumpulkan informasi dari berbagai sumber dan diskusi dengan teman untuk memecahkan persoalan yang mereka hadapi. Dengan menerapkan model perkuliahan Problem Based Instruction diharapkan dapat meningkatkan hasil belajar mahasiswa. Dengan adanya model perkuliahan Problem Based Instruction mahasiswa semakin mampu memahami materi kuliahnya dan mampu mengaplikasikannya dalam kehidupannya sehari-hari. Atas dasar inilah penulis tertarik melakukan penelitian yang berjudul: "Penerapan Model Permbelajaran Problem Based Instruction Untuk Meningkatkan Hasil Belajar Matakuliah Konsep Dasar PKn SD Subtema 1 Keberagaman Budaya Bangsaku Pada Mahasiswa PGSD Semester 1 T. A. 2019/2020“. 


\section{METODE PENELITIAN}

\section{Jenis penelitian}

Jenis penelitian ini adalah penelitian tindakan kelas (Classroom Action Research) yaitu penelitian yang dilakukan dosen dikelasnya dengan cara merencanakan, melaksanakan, mengamati, merefleksikan tindakan secara kolaboratif dan partisipatif untuk memperbaiki kinerja dosen sehingga hasil belajar mahasiswa. Tindakan ini dilakukan dengan 2 tahapan sesuai dengan perubahan yang ingin dicapai. Siklus I dirancang dengan dasar hasil pratindakan dengan mengindentifikasi masalah yang ada. Siklus II didasarkan atas hasil refleksi siklus pertama. Penelitian tindakan ini dirancang dengan proses pengkajian berdaur (cyclical) yang terdiri dari 4 fase kegiatan yaitu: merencanakan, melakukan tindakan, mengamati dan merefleksi. Penelitian ini dilaksanakan pada Group P2 mahasiswa PGSD Semester 1 T. A. 2019/ 2020. Populasi dalam penelitian ini adalah seluruh mahasiswa PGSD Semester 1 T. A. 2019/ 2020. Sampel adalah bagian yang dimiliki dari populasi. Objek pada penelitian ini adalah satu kelas yaitu group P2 berjumlah 40 orang.

\section{Instrumen Pengumpulan Data}

Alat yang digunakan dalam pengumpulan data penelitian ini adalah dengan observasi, tes, laporan, studi dokumentasi. Observasi dilakukan dengan cara mengamati langsung ke lapangan untuk memperoleh data-data yang berhubungan dengan objek penelitian dan juga tes buatan dosen berbentuk soal pilihan ganda yang terdiri dari 4 pilihan. Tes ini dilakukan untuk mengukur ketuntasan hasil belajar mahasiswa.. Tes ini berbentuk pilihan berganda sebanyak 30 soal dengan empat pilihan jawaban dan hanya satu jawaban yang benar. Penyusunan tes yang diukur berdasarkan penilaian aspek kognitif dan disesuaikan dengan kompetensi yang ingin dicapai dalam perkuliahan yaitu tingkat ingatan $(\mathrm{C} 1)$, pemahaman $(\mathrm{C} 2)$, dan aplikasi (C3), analisis (C4).

\section{Uji Coba Instrumen Tes \\ Uji validitas}

Uji validitas dilakukan untuk menentukan tes yang digunakan benar-benar mengukur apa yang harus diukur. Untuk pengujian ini dilakukan dengan menggunakan rumus koefisien korelasi Product Moment yang dikemukakan oleh Pearson, dengan rumus:

$\operatorname{rxy}=\frac{\mathrm{N} \sum \mathrm{XY}-\left(\sum \mathrm{X}\right)\left(\sum \mathrm{Y}\right)}{\sqrt{\left\{\mathrm{N} \sum \mathrm{X}^{2}-\left(\sum \mathrm{X}\right)^{2}\right\}\left\{\mathrm{N} \sum \mathrm{Y}^{2}-(\Sigma \mathrm{Y})^{2}\right\}}}$

Dengan ketentuan :

$$
\begin{aligned}
\sum_{\mathrm{X}} & =\text { Jumlah Produk Skor } \mathrm{X} \\
\sum_{\mathrm{Y}} & =\text { Jumlah Produk Skor } \mathrm{Y} \\
\mathrm{N} & =\text { Banyak Mahasiswa } \\
\text { rxy } & =\text { Koefisien Korelasi Skor Butir dan Skor Total }
\end{aligned}
$$

Untuk menafsirkan harga validitas setiap item dibandingkan dengan harga kritik validitas Product Moment (taraf signifikan $\alpha=0,005$ ) dengan criteria rhit $>$ rtab, maka item tersebut dinyatakan valid atau sebaliknya.

Untuk mengadakan interpretasi besarnya korelasi adalah sebagai berikut:

$0,800<\operatorname{rxy} \leq 1,00=$ validitas sangat tinggi

$0,600<$ rxy $\leq 0,800=$ validitas tinggi (baik)

$0,400<$ rxy $\leq 0,600=$ validitas cukup

$0,200<$ rxy $\leq 0,400=$ validitas kurang

$0,000<\operatorname{rxy} \leq 0,200=$ validitas sangat kurang (tidak valid)

(Arikunto, 2009) 


\section{Reliabilitas Tes}

Tes dapat dipercaya jika memberikan hasil yang tetap walaupun diujikan berulang kali selalu menunjukkan suatu ketetapan. Pilihan berganda, reliabilitasnya dapat dihitung dengan menggunakan rumus KR-20 oleh Kuder Richardson yaitu:

$\mathrm{r} 11=\left[\frac{\mathrm{n}}{\mathrm{n}-1}\right]\left[\frac{\mathrm{S}^{2}-\sum \mathrm{pq}}{\mathrm{S}^{2}}\right]$

Keterangan:

$$
\begin{array}{ll}
\mathrm{r} 11 & =\text { Reliabilitas tes } \\
\mathrm{n} & =\text { Banyaknya soal } \\
\mathrm{S} & =\text { Standar Deviasi dari tes } \\
\sum_{\mathrm{pq}} & =\text { Jumlah hasil perkalian } \mathrm{p} \text { dan } \mathrm{q} \\
\mathrm{p} & =\text { Proporsi subjek yang menjawab benar } \\
\mathrm{q} & =\text { Proporsi subjek yang menjawab salah }
\end{array}
$$

Untuk menafsirkan harga reliabilitas tes, maka harga tersebut dikonfirmasikan dengan harga kritik rtab Product Moment dengan $\alpha=0,05$. Jika rhit $\geq$ rtab, maka tes tersebut dinyatakan reliable yang berarti dapat dipercaya.

Adapun kriteria reliabilitas suatu tes sebagai berikut:

$$
\begin{array}{ll}
0,00-0,20 & =\text { sangat rendah } \\
0,21-0,40 & =\text { rendah } \\
0,41-0,60 & =\text { sedang } \\
0,61-0,80 & =\text { tinggi } \\
0,81-1,00 & =\text { sangat tinggi }
\end{array}
$$

(Arikunto, 2017)

\section{Teknik Analisis Data}

Analisa data yang digunakan dalam penelitian ini adalah analisis deskriptif kuantitatif yaitu : Ketuntasan hasil belajar dianalisis secara deskriptif dengan melihat skor hasil belajar, yang diperoleh dari penjumlahan skor post test dan hasil LKS yang kemudian hasilnya dibagi dua untuk tiap siklus . Skor nilai ketuntasan belajar mahasiswa digunakan rumus sebagai berikut:

Untuk menghitung ketuntasan secara individu maka digunakan rumus:

$$
\text { Ketuntasan Individual }=\frac{\text { jumlah skor }}{\text { jumlah skor maksimal }} \times 100
$$

Sedangkan untuk menghitung ketuntasan klasikal digunakan rumus:

$$
\text { Ketuntasan Klasikal }=\frac{\text { Jumlah siswa tuntas }}{\text { jumlah seluruh siswa }} \times 100
$$

Ketuntasan Individual : Jika mahasiswa mencapai nilai $\geq 65$ Ketuntasan Klasikal : Jika $\geq 85 \%$ dari seluruh mahasiswa mencapai ketuntasan $\geq 65$. Yang menjadi indikator keberhasilan penelitian tindakan ini adalah apabila ada peningkatan hasil dari setiap siklus yaitu tercapainya ketuntasan individual $\geq 65$ dan jumlah mahasiswa yang mencapai nilai tersebut $\geq 85 \%$.

\section{HASIL DAN PEMBAHASAN PENELITIAN}

Penelitian yang dilakukan di prodi PGSD Universitas HKBP Nommensen Pematangsiantar menerapkan model perkuliahan Problem Based Instruction berdasarkan kurikulum 2013 edisi revisi pada Subtema 1 Keberagaman Budaya Bangsaku di group P2 PGSD Semester I Tahun Pelajaran 2019/2020. Dalam penelitian ini terdapat dua siklus, karena pada siklus I perkuliahan tidak tuntas atau belum mencapai KKM yang ditetapkan yaitu 72, maka penelitian ini dilanjutkan ke Siklus II. Adapun tahapan - tahapan yang dilakukan sebagai berikut: 


\section{Pratindakan}

Pelaksanaan pratindakan yang dilakukan adalah kegiatan observasi ke prodi PGSD, pendosensan izin pelaksanaan penelitian, serta melakukan wawancara dengan dosen pengampuh matakuliah konsep dasar PKn untuk mengetahui permasalahan dan kendala yang dihadapi selama proses perkuliahan. Dari kendala ini peneliti bersama dosen berusaha mengatasi permasalahan tersebut dengan menggunakan model Problem Based Instruction. Pemilihan teknik perkuliahan ini diharapkan dapat memudahkan mahasiswa dalam Subtema 1 Keberagaman Budaya Bangsaku.

\section{Siklus I}

\section{Perencanaan}

Sejalan dengan hasil yang ditemukan pada tahap pratindakan maka peneliti dan dosen mempersiapkan beberapa hal yakni: Menyusun kegiatan perkuliahan sesuai dengan model Problem Based Instruction, sehingga proses perkuliahan yang akan diberikan kepada mahasiswa optimal, Membuat penjelasan mengenai langkah-langkah perkuliahan dengan menggunakan model Problem Based Instruction, Menggunakan nilai ulangan materi sebelumnya untuk skor atau nilai dasar setiap mahasiswa, Kemudian mahasiswa dibagi menjadi 8 kelompok dengan jumlah 1 kelompok 4-5 orang dan asisten setiap kelompok adalah mahasiswa yang memiliki skor dasar tertinggi, Menyiapkan lembar kegiatan mahasiswa, Menetapkan aspek-aspek aktivitas belajar mahasiswa yang akan diamati selama proses perkuliahan sesuai dengan model Problem Based Instruction, Untuk mengetahui hasil belajar yang telah diberikan, mahasiswa diberikan LKS dan soal post test diakhir pelajaran.

\section{Tindakan}

Tindakan merupakan penerapan dari kegiatan perencanaan yang telah dibuat. Adapun kegiatan perkuliahan dalam satu kali pertemuan 2 x 50 menit. Pada tahap pelaksanaan tindakan ini dosen melakukan beberapa hal: Pada awal masuk dosen mengucapkan salam pada mahasiswa dan memberikan motivasi pada mahasiswa (5 menit . Sebelum pelajaran dimulai dosen menjelasan mengenai langkah-langkah perkuliahan dengan menggunakan model Problem Based Instruction yang akan dilaksanakan selama proses perkuliahan berlangsung, Dosen memaparkan tema dan subtema yang akan dibahas, Dosen bersama-sama dengan mahasiswa membuat kesimpulan terhadap Subtema 1 Keberagaman Budaya Bangsaku, Hasil post test yang dilakukan memperlihatkan kemampuan mahasiswa mencapai KKM secara individual mencapai 17 orang mahasiswa atau 42,5\% secara klasikal, dan yang belum memenuhi KKM mencapai 23 orang mahasiswa atau 57,5\%. Untuk lebih jelasnya dapat dilihat pada tabel berikut ini: Hasil temuan ini menunjukkan adanya permasalahan mahasiswa dalam proses perkuliahan. Hasil perkuliahan tidak hanya menyangkut nilai post test tapi juga nilai LKS. Untuk LKS siklus I terdapat 33 orang yang tuntas dalam perkuliahan sekitar $(82,50 \%)$ dan mahasiswa yang tidak tuntas sebanyak 7 orang $(17,50 \%)$.

\section{Observasi}

Observasi yang dilakukan peneliti mulai dari awal pelaksanaan sampai akhir pelaksanaan tindakan. Hasil pengamatan, peneliti telah melaksanakan perkuliahan sesuai dengan skenario yang telah dirancang. Untuk menarik perhatian mahasiswa, peneliti memberikan pertanyaan-pertanyaan sesuai dengan materi yang disampaikan. Hasil observasi yang di dapat terlihat mahasiswa semakin aktif dan berpartisipasi 
dalam belajar. Hasil pengamatan aktivitas belajar mahasiswa menunjukkan bahwa siklus pertama pada umumnya mahasiswa kurang aktif dalam proses perkuliahan, dilihat dari 3 aspek yaitu memperhatikan sebanyak (45,24\%), memberi tanggapan sebanyak $(48,41 \%)$ dan bersemangat sebanyak $(46,83 \%)$ dengan kategori kurang. Sedangkan untuk aspek bertanya sebanyak $(47,62 \%)$ dan menyalin sebanyak $(48,41$ $\%)$ tergolong dalam kategori cukup, sehingga secara klasikal hasil observasi aktivitas belajar mahasiswa, menunjukan rata-rata sebesar 1,48 (67,72\%), dimana nilai tersebut masuk dalam kategori kurang sehingga perlu dilakukan perbaikan pada siklus berikutnya. Ranah psikomotorik (pembentukan konsep, interpretasi data, aplikasi prinsip, kemampuan membuat prinsip) yang masing-masing aspek diberi skor 1-4. Diperoleh nilai rata-rata ranah psikomotorik sebesar 41,72 atau dengan kata lain mahasiswa cukup aktif dalam mengikuti proses perkuliahan. Untuk ketuntasan hasil belajar mahasiswa pada siklus I mempunyai rentang nilai 33,00, dengan nilai rata-rata 66,45 ; simpangan baku (SD) sebesar 5,34 ; Median (M) sebesar 66,66 dan Modus (Mo) sebesar 66,70. Mahasiswa yang mencapai tingkat ketuntasan belajar secara individu hanya 27 orang $(67,50)$ yang memiliki nilai $\mathrm{KKM} \geq 65$. Berdasarkan gambar menunjukkan secara klasikal ketuntasan hasil belajar mahasiswa mencapai 67,50 dapat dikatakan belum mencapai tingkat ketuntasan belajar karena suatu kelas dikatakan tuntas dalam belajar jika persentase ketuntasan klasikal telah mencapai paling sedikit $85 \%$ Di akhir proses perkuliahan dosen memberikan penghargaan pada kelompok berdasarkan perolehan nilai peningkatan hasil belajar individual dari skor dasar (awal) ke skor kuis atau tes setelah bekerja dalam kelompok. Dari hasil olahan nilai post test siklus 1 maka penghargaan untuk kelompok 1 dan 6 mendapat predikat cukup dan kelompok 2,3,4,5,7,8 mendapat predikat baik. Perhitungan skor kelompok dilakukan dengan cara menjumlahkan masing-masing perkembangan skor individu dan hasilnya dibagi sesuai jumlah kelompok. Data hasil pengamatan pada Siklus I dijadikan acuan dalam pemberian tindakan pada siklus berikutnya sebagai upaya meningkatkan hasil belajar mahasiswa pada subtema 1 Keberagaman Budaya Bangsaku. Untuk lebih jelasnya perhatikan pada tabel ketuntasan hasil belajar mahasiswa Siklus I.

\section{Refleksi}

Refleksi dilakukan berdasarkan hasil analisis data perolehan tes dan observasi yang dilakukan. Hasil ini akan menjadi bahan masukan dalam menentukantindakan perbaikan untuk berikutnya. Pada siklus I ini dari hasil penelitian menunjukkan masih adanya permasalahan yaitu : 1) Mahasiswa yang takut dan kurang berani dalam memberikan pertanyaan serta menyampaikan pendapat, karena takut pertanyaan ataupun jawaban yang di berikan salah dan teman-temannya menertawakannya dan dari hal ini berdampak pada aktivitas mahasiswa dalam bertanya dan memberi tanggapan kurang aktif. 2) Mahasiswa yang kurang serius dalam perkuliahan terlihat dari ketika mendengarkan penjelasan dosen, selain itu masih ada mahasiswa yang ribut sehingga mengganggu aktivitas belajar. 3) Masih ada mahasiswa yang kurang bersemangat, merasa malu dan takut untuk mengeluarkan pertanyaan dan tanggapan karena mereka belum terbiasa untuk melakukan aktivitas bertanya atau memberi tanggapan didalam kelas, hal ini diketahui dari hasil tanya jawab peneliti dengan mahasiswa yang diteliti diluar jam pelajaran. 4) hasil belajar yang di peroleh mahasiswa melalui LKS dan post tes belum optimal dapat dilihat dari hasil siklus pertama terdapat 13 mahasiswa yang tidak tuntas hal ini dikarenakan mahasiswa kurang serius dalam melaksanakan kegiatan perkuliahan. 


\section{Siklus II}

\section{Perencanaan}

Sama halnya seperti perencanaan pada siklus I, pada siklus kedua ini pun peneliti dan dosen kembali menyusun rencana pelaksanaan semester (RPS) yang dijalankan agar proses belajar mengajar dapat berlangsung dengan baik. Untuk memberikan motivasi kepada mahasisw, Dosen memberitahukan hasil belajar serta skor aktivitas belajar kepada mahasiswa pada siklus I agarmahasiswa lebih semangat lagi dalam belajar, serta bagi mahasiswa yang memperoleh nilai dan skor yang rendah teguran dan arahan supaya saat proses perkuliahan selanjutnya dapat berjalan dengan baik. Berdasarkan permasalahan yang ada pada siklus I maka pada siklus II peneliti dan dosen group P2 PGSD melakukan upaya untuk mengatasi masalah tersebut. Pada siklus II diambil langkah-langkah berikut : Melaksanakan proses perkuliahan sesuai langkah-langkah yang telah disusun dalam rencana pelaksanaan semester (RPS), Meningkatkan kerjasama antara peneliti dalam melakukan penilaian terhadap aktivitas mahasiswa, Dosen memberikan penjelasan kepada mahasiswa agar lebih berperan dalam kegiatan diskusi, Dosen menghimbau mahasiswa supaya tidak perlu takut dan harus berani dalam menyampaikan pertanyaan ataupun tanggapan, dan bagi mahasiswa yang kurang tepat memberikan jawaban akan dibantu oleh dosen untuk meluruskannya, Dosen menghimbau mahasiswa untuk dapat mengikuti pelajaran dengan serius sehingga hasil nilai yang akan di peroleh semakin meningkat mengingat pada pertemuan pertama masih terdapat 13 mahasiswa yang tidak tuntas dalam menjawab Post Tes dan LKS.

\section{Tindakan}

Pada tahap ini, rencana tentang Subtema 1 Keberagaman budaya bangsaku yang telah disusun berdasarkan tahap perencanaan, dilaksanakan selama 1 jam pelajaran ( $2 \times 50$ menit ). Pada siklus II ini mahasiswa diharapkan dapat lebih memahami materi dengan lebih baik Pada kegiatan pendahuluan dosen mengucapkan salam terlebih dahulu, menyampaikan indikator yang ingin dicapai serta memotivasi mahasiswa. Pada kegiatan inti dosen menjelaskan materi yang akan disampaikan dan menyampaikan langkah-langkah melakukan diskusi dengan model problem based instruction. Kemudian mahasiswa duduk sesuai dengan kelompok yang telah dibagi sebelumnya. Pada setiap kelompok diberikan Lembar Kegiatan Mahasiswa (LKS), anggota-anggota kelompok mengerjakan dengan ketentuan bahwa setiap orang mahasiswa harus bekerja sama mencari dan menjawab soal yang tersedia pada lembar kegiatan mahasiswa. Setiap kelompok diberikan kesempatan untuk menanyakan kepada dosen atau peneliti tentang soal-soal yang kurang dimengerti. Dalam siklus II dilakukan kegiatan perkuliahan yang lebih intensif, sehingga pelaksanaanya lebih efektif dan efisien. Setelah perkuliahan berakhir selanjutnya dilakukan tes hasil belajar (post test) untuk mengetahui penguasaan mahasiswa. Hasil post test yang dilakukan memperlihatkan kemampuan mahasiswa mencapai KKM secara individual mencapai 35 orang mahasiswa atau $87,50 \%$ secara klasikal, dan yang belum memenuhi KKM mencapai 5 orang mahasiswa atau 12,50\%. Setelah diadakan refleksi dari hasil temuan siklus I maka dalam siklus II proses perkuliahan berhasil secara individual yang dapat dilihat dari nilai post test dan juga nilai LKS. Sebanyak 39 (97,50\%) mahasiswa dapat nilai LKS yang meningkat dari sebelumnya dan berikut dijelaskan distribusi nilai LKS setiap mahasiswa.

\section{Observasi}

Pada tahap ini pengamatan dilakukan sama seperti pada siklus I. Berdasarkan hasil 
pengamatan observer kemudian ditabulasikan dan dihitung persentasenya, observasi dilakukan setiap pertemuan, secara umum aktivitas belajar mahasiswa pada siklus II mengalami peningkatan, adapun jenis aktivitas yang diamati adalah meliputi: Ranah afektif (memperhatikan, bertanya, menyalin, memberi tanggapan, bersemangat yang masing-masing aspek diberi skor 1-3). Rata-rata aktivitas belajar mahasiswa di siklus II mengalami peningkatan yang cukup signifikan secara klasikal mencapai skor 2,41. Untuk aspek memperhatikan $(84,17 \%)$, aspek bertanya $(84,17 \%)$, aspek menyalin $(85,83 \%)$, memberi tanggapan $(85,83 \%)$, dan aspek bersemangat $(86,67 \%)$. Sehingga secara umum rata-rata aktivitas mahasiswa di siklus II tergolong baik. Setiap aspek aktivitas belajar mahasiswa mengalami peningkatan dari Siklus I ke Siklus II. Untuk aspek memperhatikan meningkat $(1,10 \%)$, bertanya $(1,03 \%)$, menyalin $(1,04 \%)$, memberi tanggapan $(1,09 \%)$, dan bersemangat $(1,12 \%)$. Secara visual:

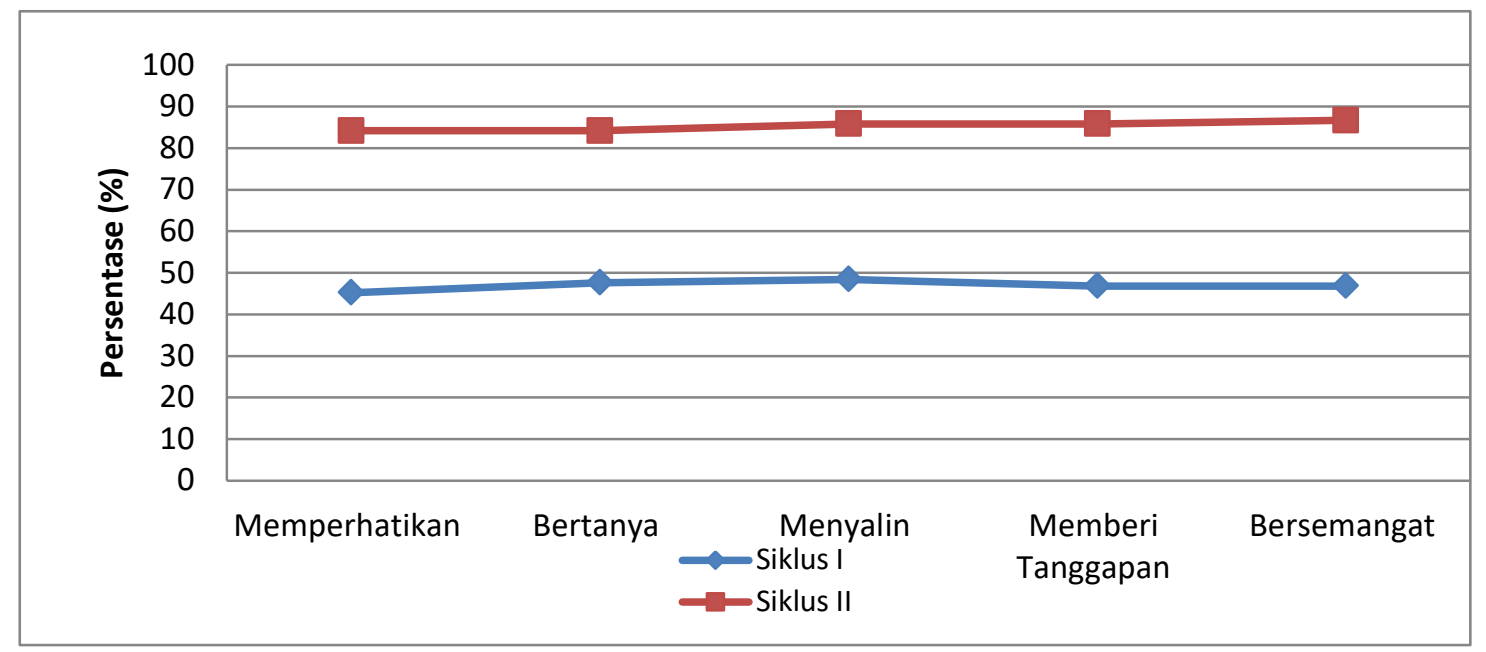

\section{Gambar 1 Grafik Peningkatan Aktivitas (Afektif) Belajar Mahasiswa dari Siklus I ke Siklus II}

Terjadi peningkatan aktivitas belajar mahasiswa dari Siklus I ke Siklus II sebesar $38,36 \%$ artinya terdapat peningkatan aktivitas belajar mahasiswa pada Subtema 1 Keberagaman Budaya Bangsaku dengan menggunakan model problem based instruction. Ranah psikomotorik (pembentukan konsep, interpretasi data, aplikasi prinsip, kemampuan membuat prinsip) yang masing-masing aspek diberi skor 1-4. Diperoleh nilai rata-rata ranah psikomotorik sebesar 82,03 atau dengan kata lain mahasiswa sangat aktif dalam mengikuti proses perkuliahan.

\section{Peningkatan Aktivitas Belajar Mahasiswa Dengan Menggunakan Model Perkuliahan Kooperatif Problem Based Instruction}

Dari hasil penelitian yang dilakukan, terlihat bahwa perbaikan perkuliahan pada siklus II berdasarkan hasil refleksi pada siklus I membawa perubahan yang besar, dilihat dari kesiapan belajarnya, aktivitas mahasiswa dalam mengikuti kegiatan perkuliahan yang ditunjukkan mahasiswa dalam mengikuti kegiatan perkuliahan melalui observasi yang dilakukan. Berdasarkan observasi yang dilakukan oleh pengamat, secara umum antusias mahasiswa dalam perkuliahan, namun masih ada beberapa orang mahasiswa kurang aktif, hal ini disebabkan antara lain karena: 1) mahasiswa yang takut dan kurang berani dalam memberikan pertanyaan serta menyampaikan pendapat, karena takut pertanyaan ataupun jawaban yang di berikan salah dan teman-temannya mentertawakannya dan dari hal ini berdampak pada aktivitas mahasiswa dalam 
bertanya dan memberi tanggapan kurang aktif. 2) mahasiswa yang kurang serius dalam perkuliahan terlihat dari ketika mendengarkan penjelasan dosen, selain itu masih ada mahasiswa yang ribut sehingga mengganggu aktivitas belajar. 3) Masih ada mahasiswa yang kurang bersemangat, merasa malu dan takut untuk mengeluarkan pertanyaan dan tanggapan karena mereka belum terbiasa untuk melakukan aktivitas bertanya atau memberi tanggapan didalam kelas, hal ini diketahui dari hasil tanya jawab peneliti dengan mahasiswa yang diteliti diluar jam pelajaran. 4) hasil belajar yang di peroleh mahasiswa melalui LKS dan post tes belum optimal dapat dilihat dari hasil siklus pertama terdapat 13 mahasiswa yang tidak tuntas hal ini dikarenakan mahasiswa kurang serius dalam melaksanakan kegiatan perkuliahan.

\section{Peningkatan Hasil Belajar Mahasiswa dengan Menggunakan Model Perkuliahan Kooperatif Problem Based Instruction}

Berdasarkan hasil LKS mahasiswa dengan menggunakan model problem based instruction pada umumnya dikatakan baik. Rata-rata hasil LKS mahasiswa di siklus pertama sebesar $67,00 \%$ dan di siklus kedua meningkat menjadi 84,50\%. Hasil ketuntasan hasil belajar mahasiswa pada siklus I belum mencapai nilai standart KKM. Hasil ketuntasan mahasiswa diperoleh dari penjumlahan LKS mahasiswa dengan hasil post test yang selanjutnya dibagi dua, yang mencapai tingkat ketuntasan belajar secara individu hanya 27 mahasiswa yang memiliki nilai $\mathrm{KKM} \geq 65$ dengan rata-rata persentase hanya mencapai $67,50 \%$ sehingga tidak mencapai ketuntasan hasil belajar secara klasikal. Sesuai dengan indikator ketuntasan hasil belajar individual jika mahasiswa mencapai skor ketuntasan $\geq 65$ sedangkan ketuntasan belajar klasikal jika $\geq 85 \%$ dari seluruh mahasiswa mencapai skor ketuntasan $\geq 65$. Mahasiswa akan lebih mudah menerima pelajaran jika mahasiswa merasa nyaman dalam perkuliahan. Sehingga proses perkuliahan secara menyenangkan dan aktivitas mahasiswa dapat meningkat. Problem based instruction mendorong mahasiswa untuk meningkatkan semangat kerjasama didalam kelompok. Hal ini sesuai dengan pendapat Lona Curran (1994) dalam Isjoni (2017) yang mengatakan bahwa model problem based instruction dirancang untuk mahasiswa berkelompok sambil belajar mengenai suatu konsep atau topik dalam suasana yang menyenangkan.

Berdasarkan penilaian LKS dan post test pada siklus II diperoleh kesimpulan bahwa ketuntasan hasil belajar meningkat dari setiap siklus yang telah dilaksanakan. Rata-rata ketuntasan hasil belajar mahasiswa di siklus II sebanyak 87,50\% atau terdapat 35 orang mahasiswa yang berhasil (lulus). Ada 5 orang mahasiswa yang tidak tuntas dengan ketentuan KKM, untuk mengatasi hal tersebut maka dilakukan remedial, mahasiswa ditugasi mengerjakan soal dan LKS guna meningkatkan nilai mahasiswa tersebut. Secara umum dapat disimpulkan bahwa dengan menggunakan model problem based instruction pada materi subtema 1 Keberagaman budaya bangsaku dapat meningkatkan aktivitas dan hasil belajar mahasiswa.

\section{PENUTUP}

Berdasarkan hasil penelitian yang dilakukan maka diperoleh kesimpulan sebagai berikut : Penggunaan model kooperatif Problem Based Instruction berdasarkan penelitian ini dapat meningkatkan aktivitas belajar mahasiswa, dari segi afektif yaitu sebesar 38,36 \%. Dan jika dilihat dari setiap aspek aktivitas belajar mahasiswa yaitu kemampuan memperhatikan meningkat $1,10 \%$, bertanya $1,03 \%$, menyalin $1,04 \%$, memberi tanggapan $1,09 \%$, dan bersemangat 1,12\%. Dari segi psikomotorik meningkat sebesar $40,31 \%$ dilihat dari indicator 1 maka nilai peningkatan sebesar 
$1,10 \%$, indicator $2(1,03 \%)$, indicator $3(1,04 \%)$, indicator $4(1,09 \%)$. Dengan demikian teknik perkuliahan ini dapat membantu mahasiswa untuk meningkatkan aktivitas mahasiswa selama perkuliahan. Model perkuliahan kooperatif Problem Based Instruction dapat meningkatkan hasil belajar mahasiswa pada Subtema 1 Keberagaman Budaya Bangsaku Peningkatan hasil belajar mahasiswa dari siklus I $(67,50)$ ke siklus II $(87,50)$ sebesar $20 \%$ (tuntas secara klasikal). Hasil belajar diperoleh dari hasil LKS mahasiswa dan tes hasil belajar.

\section{DAFTAR PUSTAKA}

Akdon. 2006. Strategic Managemen for Educational Management. Bandung: Alfabeta.

Antman, L. \& Olsson, T. (2007). A two -Dimensional Matrix Model for Analysing Scholarly Approaches to Teaching and Learning. In Rust, C. (Ed) Improving Student Learning Through Teaching, The Oxford Centre forStaff and Learning Development.

Apelgren, K. \& Giertz, B. (2010). "A Swedish Perpective on Pedagogical Competence -A key to Pedagogical Devcelopment and Quality in Higher Education". In Ryegard, A., Apelgreen, K. \& Olsson, T. (2010). A Swedish Perspective on Pedagogical Competence.Division for Development of Teaching and Learning. Uppsala University.

Arikunto, S. (2006). Prosedur Penelitian Suatu Pendekatan Praktek. Jakarta: PT. Rineka Cipta

Cohen,J (2006).Social,Emotional,Ethical and Academic Education: Creating a Climate for Learning, Participating in Democracy and well-being. Harvard Educational Review,76(2),201-237

Costly, Dan L \& Todd ralp. (1987). Human Relation In Organization. USA. St. Paul west Publising Company.

Hillman, Moertimonce. (1995). Key Characteristics Effective School: A Review Of school Effectiveness Reseacrh. London: OFSTE

Komariah, A. \& Triana, C. (2010). Visionary leadership menuju sekolah efektif. Jakarta: Bumi Aksara.

MacBeath, John, dan Mortimore, Peter. (2001). Improving School Effectiveness. Open University Press.

Mahmood, Tariq dan Ahmed Mukhtar (2013). Assessing the Pedagogical Competences of Teacher Educators in the Teacher Education Institution of Pakistan. University of Education, Division of Education College road Town ship, Lahore Academic Journal of Interdisciplinary Studies Published by MCSER-CEMAS-Sapienza University of Rome Vol 2 No 1 March 2013

Muhammad, Arni. (2007). Komunikasi Organisasi. Jakarta: Bumi Aksara.

Mulyasa. (2004). Manajemen Berbasis Sekolah. Bandung: Pt. Remaja Rsdakarya.

Olatoye, R.A. (2004). Interest in Schooling as a Determinant of Secondary School Students 